特発性上腸間膜静脈，門脈血栓症による広範囲小腸壊死をきたした 1 例

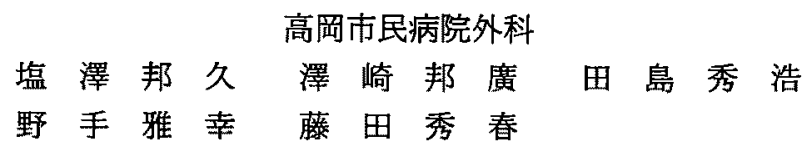

稀な疾患である上腸間膜静脈・門脈血栓症による広範囲小腸壊死の1例を経験した。 症例は66歳, 男性. 主訴は腹痛. 腹部所見で強度の圧痛, 自発痛を認め, 腹部 CTで 腹水，小腸の限局性の肥厚を指摘されたため絞㧪性イレウスを疑い開腹術を施行した。

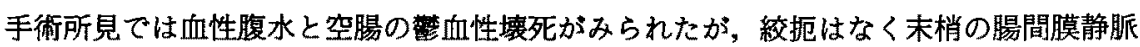
に血栓を認めたため，上腸間膜静脈血栓症と診断し小腸部分切除を施行した．術後は抗 凝固療法を行ったが，術後 2 日目に腹痛が再燃したため，上腸間膜静脈血栓症の増悪に よる腸管壊死の診断で再開腹し，広範囲小腸切除を施行した。残存小腸は約 $65 \mathrm{~cm}$ となっ た. 術後再じ血栓溶解療法，抗疑固療法，ワーファリンの内服を行い，血栓の消失はみ られなかったが術後44日目に軽快退院した。

本症例は凝固線溶系には全く異常を認めず，特発性と猃断した。

索引用語：上腸間膜静脈血栓症, 聞脈血栓症, 厇範囲小腸壊死

はじめに

急性腹症の中でも極めて稀とされる上腸間膜静脈, 門脈血栓症は特異的症状に乏しく，経過観察のみで軽 快する軽症例から，循環障害による広範な腸管壊死を きたす重症例まで様々で，早期猃断は困難である，今 回われわれは上腸間膜静脈, 門脈血栓症による広䇢囲 小腸壊死をきたした 1 例を経験したので文献的考察を 加え報告する。

\section{症例}

患者：66歳, 男性.

主訴：腹痛, 悪心, 嘔吐.

家族歴・既往歴：特記すべきことなし。

現病歴：1998年 4 月より㥜瀴演で当院通院中であっ たが，同年 5 月，㔖然激しい腹痛，悪心，嘔吐が出現 したため緊急入院となった。

入院時現症：身長 $165 \mathrm{~cm}, 65 \mathrm{~kg}$. 結膜に貧血, 黄疸 なし. 腹部は全体的に膨隆し, 自発痛および圧痛が強 度であったが、はっきりした筋性防御は認めなかった。

入院時検查所見 : 白血球 $9,900 / \mathrm{mm}^{2}$, CRP $5.5 \mathrm{mg} /$

2002 年 4 月 30 日受付 2002 年11月19日採用

〈所属施設住所〉

₹933-8550 高岡市宣町 4-1 dl と炎症所見および TP, Alb の低下が認められたが， その他凝固系などには異常を認めなかった(表 1 ), 腹 部単純X線検査では小腸ガスを少量認めるのみで, 腹 腔内遊離ガス，二ボーは認めなかった．腹部 CT では 腸管の著明な拡張と限局性の腸管壁の肥厚を認めたた め身体症状と合わせて絞拒性イレウスの猃断で開腹手 術を施行した（図 1 )。

手術所見 ( 1 回目)：開腹すると絞扼はなく，血性腹 水がみられ，小腸が Treitz 靶帯より $50 \mathrm{~cm}$ の部位より 約 $50 \mathrm{~cm}$ にわたって暗赤色に変色し, 腸管壊死をきた

\section{表 1 入院時検查所見}

\begin{tabular}{lclc}
\hline WBC & $9,900 / \mu \mathrm{l}$ & Amy & $84 \mathrm{IU} / 1$ \\
$\mathrm{RBC}$ & $467 \times 10^{4} / \mu \mathrm{l}$ & $\mathrm{T}-\mathrm{Bill}$ & $1.63 \mathrm{mg} / \mathrm{dl}$ \\
$\mathrm{Hb}$ & $14.7 \mathrm{~g} / \mathrm{dl}$ & $\mathrm{CPK}$ & $100 \mathrm{IU} / 1$ \\
$\mathrm{Plt}$ & $20.6 \times 10^{4} / \mu \mathrm{l}$ & $\mathrm{TP}$ & $5.0 \mathrm{mg} / \mathrm{dl}$ \\
$\mathrm{Na}$ & $137 \mathrm{mEq} / 1$ & $\mathrm{Alb}$ & $2.5 \mathrm{mg} / \mathrm{dl}$ \\
$\mathrm{K}$ & $4.8 \mathrm{mEq} / 1$ & $\mathrm{~T}-\mathrm{Cho}$ & $174 \mathrm{mg} / \mathrm{dl}$ \\
$\mathrm{Cl}$ & $103 \mathrm{mEq} / 1$ & $\mathrm{TG}$ & $48 \mathrm{mg} / \mathrm{dl}$ \\
$\mathrm{BUN}$ & $15 \mathrm{mg} / \mathrm{dl}$ & $\mathrm{PT}$ & $78 \%$ \\
$\mathrm{Cr}$ & $0.6 \mathrm{mg} / \mathrm{dl}$ & $\mathrm{APTT}$ & 36.9 秒 \\
$\mathrm{AST}$ & $16 \mathrm{IU} / 1$ & $\mathrm{HpT}$ & $83 \%$ \\
$\mathrm{ALT}$ & $22 \mathrm{IU} / 1$ & $\mathrm{FDP}$ & $<10 \mu \mathrm{g} / \mathrm{ml}$ \\
$\mathrm{LDH}$ & $434 \mathrm{IU} / \mathrm{l}$ & $\mathrm{CRP}$ & $5.5 \mathrm{mg} / \mathrm{dl}$ \\
$\mathrm{ALP}$ & $167 \mathrm{IU} / \mathrm{ml}$ & & \\
\hline
\end{tabular}


していた，壊死部を中心に小腸を $70 \mathrm{~cm}$ 切除し，端々吻 合を行った．切除標本では，粘膜面は警血が強く, 腸 管壁, 腸間膜の浮腫が著明で，末梢の腸間膜静脈に多 数の血栓を認めたため上腸間膜静脈血栓症が疑われ た.

術後経過 (1 回目)：術直後より抗凝固療法 (ヘパリ ン 5 千笚位/日)を行ったが, 第 2 病日に再び腹痛, 悪 心，嘔吐，吐血を認めたため上腸間膜静脈血栓症の増 覀による腸管䁲死を疑い，造影 CT を施行した。広範 囲にわたる著明な腸管の抎張, 腸間膜の肥厚と腹水を 諮め(図 $2 \mathrm{a}$ ), 上腸間膜静脈, 門脈は全く造影されず, 門脈本幹周囲に cavernous transformation が認めら れた(図 2 b). 以上より上腸間膜静脈，門脈血栓症の

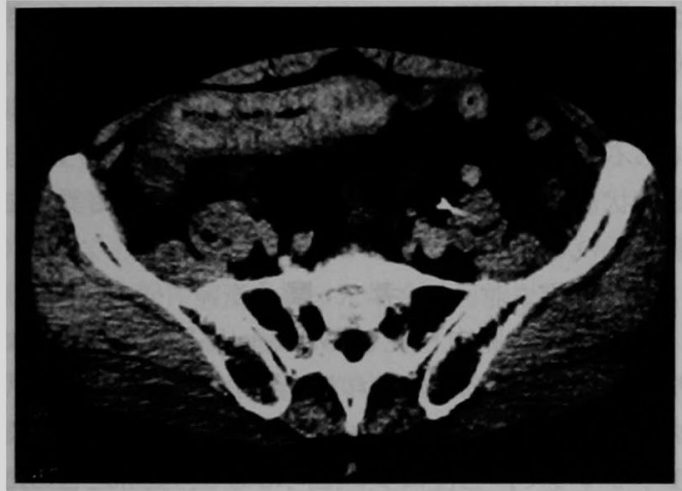

図 1 腹部 CT 検查所見：腸管の著明な拡張と限局性の 腸管壁の肥厚を認めた。

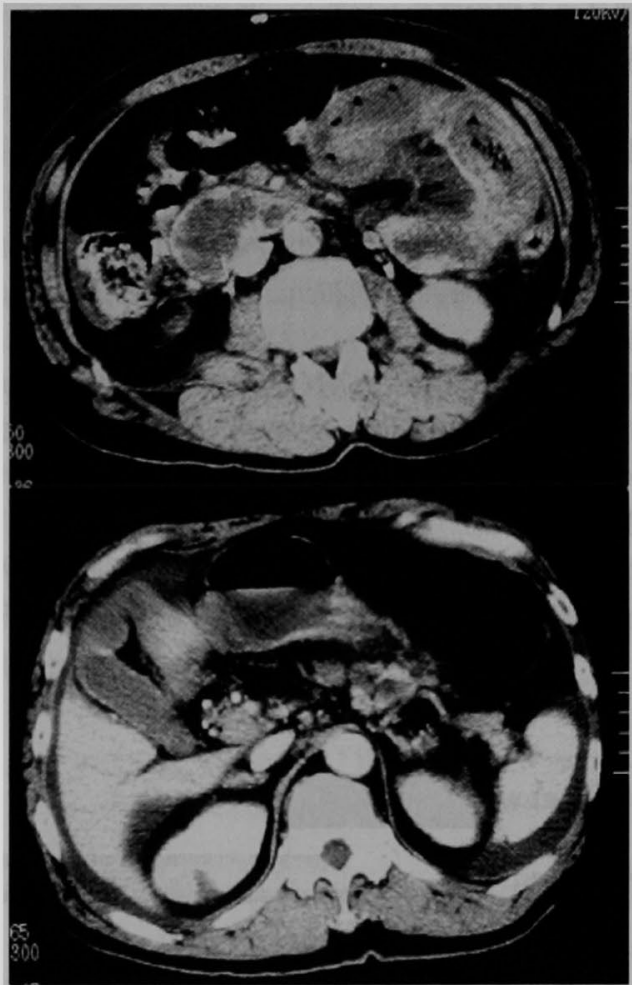

図 2 a 腹部造影 CT 検査所見：広筙囲にわたる著 明な腸管の拡張，腸間膜の肥厚と腹水を認めた。

b 腹部造影 CT 検查所見：上腸間膜静脈，門 脈は全く造影されず，門脈本幹周囲に cavernous transformation が認められた。

$\frac{a}{b}$

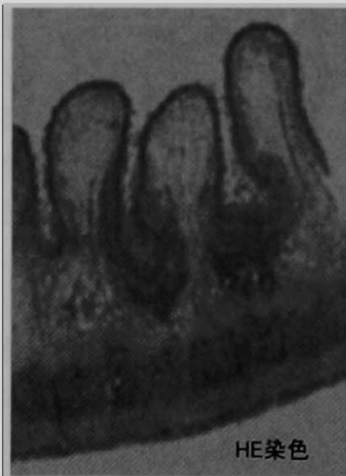

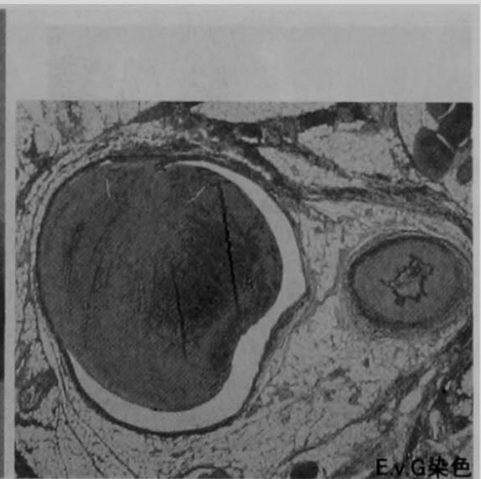

図 $3 \mathrm{a}$ 病理組織学的所見 (HE 染色ルーペ像)：粘膜全)曾が浮嗹, 出 血を伴った壤死に宿っていた。

b 病理組䇅学的所見 (E.v. G 染色 $\times 40)$ ：腸間膜動静脈には明 らかな器質的変化はなく,動脈は開存していたか，静脈内には血栓 形成を認めた。 
増悪による腸管壊死と診断し，再手術を行った。

手術所見 ( 2 回目) : 開腹すると多量の血性腹水を認 め，小腸は Treitz 勒带より $40 \mathrm{~cm}$ から吻合部をはさん

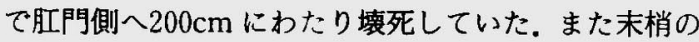
腸間膜静脈に血栓を思わせる黒い索状物を多数触知し た．壊死部を含め $350 \mathrm{~cm}$ の小腸を切除し，端々吻合を 行った. 残存小腸は口側 $20 \mathrm{~cm}$, 肛門側 $45 \mathrm{~cm}$, 計 $65 \mathrm{~cm}$ となった。

病理組織学的所見：粘膜全層が浮腫，出血を伴った 壊死に宿っていた（図 $3 \mathbf{a}$ )。また，腸間膜動静脈には 明らかな器質的変化はなく, 動脈は開存していたが, 静脈内には血栓形成を認めた（図 3 b).

術後経過（2 回目）：術直後より血栓溶解療法（ウ口 キナーゼ 6 万単位/日)。抗凝固療法 (ヘパリン 5 千単

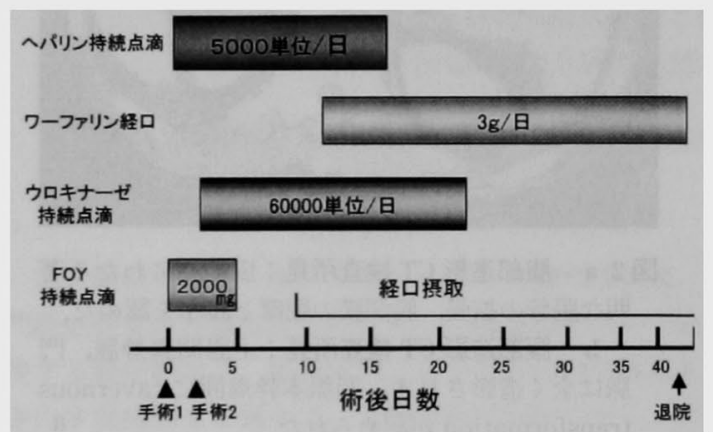

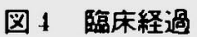

位/日）を施行した（図 4)，経過は良好で第 7 病日よ り経口䎼取を開始したが下痢，腹痛は全く認めなかっ た。第11病日からワーファリンの経口投与を開始し， 投与量はトロンボテスト $20 \%$ 台を目標に調節した。

術後に肝機能障害, 消化吸収障害, 凝固線溶系異常 は認めず，アンチトロンビンIII，プロテイン S 活性, プロテインC 活性いずれも正常範囲内であった. 以上 より，特発性上腸間膜静脈，門脈血栓症と診断した。 術後第44病日に退院したが，退院前の血管造影所見て は，動脈相には特に問題はないものの（図 5 a)，静脈 相で上腸間膜静脈および門脈が全く造影されず，依然 として血栓による閉塞と右上腹部での側副血行路の堌 生を認めた（図 5 b) 。

術後 6 力月目の造影 CT では, 入院中の造影 CT と 比へ門脈本幹周囲の cavernous transformation $の さ$ らなる発達を認めた。

現在，抗凝固療法を継続しながら外来で経過観察中 であるが, 残存小腸が $65 \mathrm{~cm}$ と短いにもかかわらず，自 覚症状は全くなく，栄養状態も良好で腹部にも異常を 認めていない.

\section{考察}

上腸間膜静脈血栓症は W'arren と Everhard"によ り1935年はじめて報告された。発症年齢は20～80歳代 までで，平均年齢は40～50歳代である，男女比は 4 ： 1〜2：1で，男性に多い傾向にある．動脈を含めた 腸間膜血管閉塞症疾患の中で腸間膜静脈血栓症の占め る頻度は15〜20 ${ }^{\circ}$ と考えられている2)，上腸間膜静脈

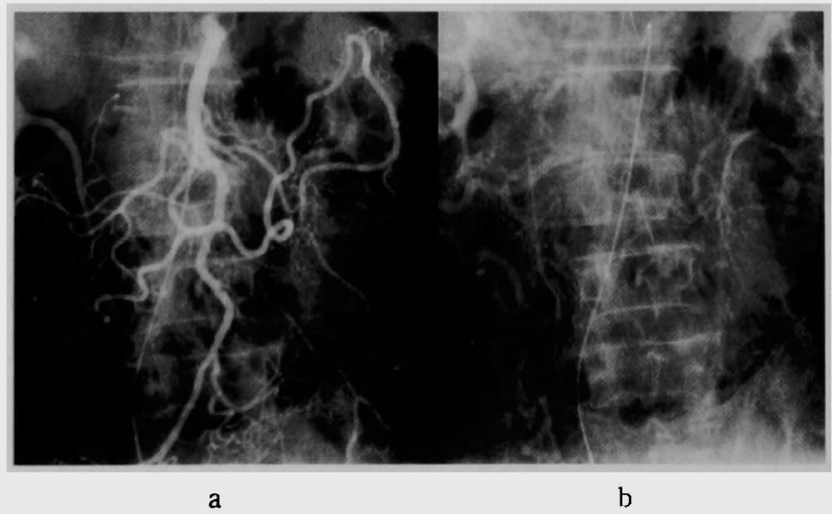

図 5 a 血管造影所見（動脈相）：動脈相には特に問題は涊めない。

b 血管造影所見 (静脈相)：棦脈相では上腸間膜静脈およよ゙門 脈が全く造影されず,依然として血栓による閉塞と考上腹部での側 副血行路の增生を認めた。 
血栓症は，原因あるいは誘因として凝固線溶異常症（ア ンチトロンビンIII, プロテイン $\mathrm{C}$, プロテイン $\mathrm{S}$, プラ スミノーゲンなどの欠損括よび異常症), 肝疾患, 感染, 炎症，外傷，腎疾患，経口避妊薬，ステロイド，悪性 腫場などがあげられるが，特発性で原因不明のものが 20 50\%存在するとされる ${ }^{3 / 4}$. 本邦で，特発性と診断 された上腸間膜静脈，䦕脈血栓症は，われわれが調ぺ た限りでは本症例も含め32例（医学中央雑誌 1986〜2001）であった。

症状は，腹痛，墨心，嘔吐，下痢，下血などで上腸 間膜静脈血栓症に特徵的な症状はそしい。 また，激し い自覚症状に比べ腹部理学的所見に乏しいため，外科 的治療が遅れ予後不良となることもあり，画像診断に よる早期発見が重要となる4)、診断にはCTが最も有 用であり，血栓症の単純 CT では早期の場合わずかに high density area 認め, 時間の経過とともに low density area となっていく ${ }^{23566}$. 造影 CT では central lucency を伴った濃染する上腸間膜静脈壁をとらえる ことが重要である25156. 自験例では症状が出現した日 が休日であったため単純 CT のみであったが，急性腹 症, 特に血管性病変を疑った場合は可能な限り造影も 試みるべきであると思われた。

治療については，発症後早期に䛦断された例や腸管 罜死に至っていないと思われる例は，原因疾患に対す る治療と，全身的あるいは選択的抗凝固，血栓溶解療 法のみで治痹したとの報告もある゙n! しかし，すでに 腸管墙死をきたしている症例では，壊死腸管の切除が 不可欠であるが，最も重要なのは切除範囲の決定であ る.腸管の viability の判定法にはいまた確立されたも のがなく2), 特に本症においては血栓の進展，あるいは 一見正常と判断される腸管領域の腸間膜血管内にもす でに血栓が形成されていることがあり，再発や縫合不 全の一因となるため健常部を十分に含めた切除が必要 と思われる ${ }^{416)}$. また，少しでも再発の兆候がみられた 場合，時を失せず再手術が必要と考えられる，保存的 療法で見るか，外科的治療に踏み切るかの判断には， 末だはっきりした見解がなく，保存的療法で治䉥した が, 早期に症状が再発し，虚血による小腸狭窄または 穿孔をきたし，結局は小腸切除を余儀なくさせられた との報告もある23788).

術後の抗凝固, 血栓溶解療法に関しては，ヘパリン は 1 万単位/日，ウロキナーゼは12〜24万単位/日投与 することが望ましい，とされているが，過去の症例を 検討してみると，ヘパリン投与量は 5 千 1 万 5 千単
位/日，6万〜24万単位/日と症例ごとに様々であり， ヘパリンまた惊ウロキナーゼ単独という症例も散在し た. 本症例に関しては，1回目の手術後へパリン投与 量が 5 千単位/日と少なめであったため治療効果が少 なく，2 回目の手術が必要になったとも考えられ，治 療莧の選択が重要であったと思われた

上腸間膜静脈血栓症は，特発性で原因不明のものが 多く,治療法においても未だはっきりした見解がない。 今後, 早期猃断, 手術の時期, 再発予防, 術後の血栓 溶解療法, 抗凝固療法などのさらなる検討が必要と考 えられた。

\section{結語}

今回われわれは, 上腸間膜静脈, 門脈血栓症による 広範囲小腸壞死をきたした 1 例を経験したので文献的 考察を加えて報告した。

\section{文献}

1) Warren $S$, Eberhard TP:Mesenteric venous thrombosis. Surge Gynecol Obstet $61: 12-21$, 1935

2）中村好宏，石部良平，池江隆正他：上腸間膜静脈 血拴症の1例. 日臨外会誌 $59: 1393-1396,1998$

3）石井貴士，島田長人，柴 忠明：上腸間膜静脈血 栓症。臨外 52：1543-1547，1997

4）高 順一，福島元彦，石井博他：特発性上腸間 膜静脈血栓症の 1 例. 日消病会誌 $94: 200-203$, 1997

5）宇田光伸，播渃敬三，村田貴史他：上晹間膜静脈 血栓症の 4 例. 臨放線 $38: 1463-1466,1993$

6）大毛宏喜, 横山 隆, 児玉 節他：急性上腸間膜 静脈血栓症の 2 手術例. 日腹部救急医会誌 18 ： $323-326,1998$

7）中澤俊郎，武井伸一，神林秀敬他：保存的治療に 上り治瘜した上晹間膜静脈血栓症の 2 例。日臨内 科医会誌 $12 ： 155-159 ， 1997$

8）日高 央, 小林清典, 國分茂博他：肝外門脈閉塞 症に合併した虚血性小腸㹟窄の 1 切除例. 日消病 会誌 $94 ： 839-844,1997$

9）関澤裕人, 松岡文章, 長田達郎他：上腸間膜静眽門脈血栓症の 1 例.日救急医会関東誌 $14: 594-$ 596, 1993

10）熊谷洋一，山崎 繁，三浦則正他：上腸間膜静眽 血栓症の 1 例。太田病年報 $31: 17-21 ， 1996$

11）浦山 博, 大竹裕志，原田 猛他：腸間膜静脈血 拴症. 外科診療 $57: 351-355,1996$ 


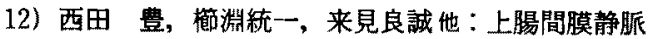
血栓症の 1 例. 臨外 $52: 91-94,1996$

13）矢野康生, 山下芳典, 花岡奉憲地：アンチトロン ビンIII欠乏症に伴う上晹間膜静脈血栓症の 1 例. 消外 $17: 1777-1781,1994$

14）杉浦禎一, 新寅紀二, 横井俊平他：プロティン S欠 乏症による上腸間膜静脈向栓症の1 例，日消外会 誌 31：2388-2391，1998

15）上原圭介，長谷川洋，小木曾清二他：上踼間膜静 脈血栓症の1例。日臨外会誌 $60: 3006-3010$, 1999

16）山内希美，山内一，田辺博他：晹間膜静脈血 栓症により広䈥围回腸壊死をきたした1例．日臨
外会誌 $60 ： 2410-2413 ， 1999$

17）藤田利枝，小原則博，天野 実他：血栓溶解浏動 注療法後に小腸狭窄を来した上腸間膜静脈血检症 の1例. 日踇外会誌 $61: 1053-1057,2000$

18）大谷 博, 水上健治, 清水貞利他：Hassab 手術後 の門脈血栓形成に対し血栓溶解療法が著効した 1

例. 日消外会誌 $34: 219-223,2001$

19）池田公正, 島野高志, 北田昌之他：プロテイン S 欠 乏症に起因した腸間膜静脈血拴症の1手術例。日 消外会誌 $35: 332-336,2002$

20）岩等友視，岩井武尚：抗血小板薬と抗凝固薬をど う使い分けるか＼cjkstart血栓症と塞恮症予防への対応。

臨成人病 $31: 943-948,2001$

\title{
A CASE OF BOWEL NECROSIS CAUSED BY PRIMARY THROMBOSIS OF THE SUPERIOR MESENTERIC VEIN AND PORTAL VEIN
}

\author{
Kunihisa SHIOZAWA, Kunihiro SAWASAKI, Hidehiro TAJIMA, \\ Masayuki NOTE and Hideharu FUJITA \\ Department of Surgery. Takaoka City Hospita!
}

A 66-year-old man referred for diffuse abdominal pain, nausea and vomiting. Emergency laparotomy underwent under a diagnosis of ileus by based on computed tomography (CT) findings. Operative findings showed intestinal gangrene and a swollen mesenterium. Massive thrombus was found in the mesenteric vein. The affected bowel was resected with end-to-end anastomosis. On postoperative day (POD) 2, he experienced of severe abdominal pain and CT showed edema of the small intestine and ascites. Reoperation showed recurrent thrombosis and the previous surgical procedure was repeated. The remaining small intestine was $65 \mathrm{~cm}$ long. Immediately after surgery, we started anticoagulation therapy. The patient recovered well and was discharged on POD 44. Coagulation studies showed no abnormality and we considered this a case of primary thrombosis. 